\title{
Corrigendum: The Lost Fish of Turkey: A Recent History of Disappeared Species and Commercial Fishery Extinctions for the Turkish Marmara and Black Seas
}

\author{
Aylin Ulman ${ }^{1,2 *}$, Mustafa Zengin ${ }^{3}$, Nazli Demirel ${ }^{4}$ and Daniel Pauly ${ }^{1}$ \\ ${ }^{1}$ Sea Around Us, Institute for the Oceans and Fisheries, The University of British Columbia, Vancouver, BC, Canada, \\ ${ }^{2}$ Mersea Marine Conservation Consulting, Fethiye, Turkey, ${ }^{3}$ Central Fisheries Research Institute, Trabzon, Turkey, ${ }^{4}$ Institute of \\ Marine Sciences and Management, Istanbul University, Istanbul, Turkey
}

Keywords: endangered species, fisheries management, extirpations, elasmobranchs, overexploitation

\section{OPEN ACCESS}

Approved by:

Frontiers Editorial Office

Frontiers Media SA, Switzerland

*Correspondence:

Aylin Ulman

uaylin@hotmail.com

Specialty section:

This article was submitted to

Marine Ecosystem Ecology,

a section of the journal

Frontiers in Marine Science

Received: 29 August 2020 Accepted: 01 September 2020

Published: 02 October 2020

Citation:

Ulman A, Zengin M, Demirel N and Pauly D (2020) Corrigendum: The Lost Fish of Turkey: A Recent History of

Disappeared Species and Commercial

Fishery Extinctions for the Turkish

Marmara and Black Seas.

Front. Mar. Sci. 7:600242

doi: 10.3389/fmars.2020.600242

\section{A Corrigendum on}

The Lost Fish of Turkey: A Recent History of Disappeared Species and Commercial Fishery Extinctions for the Turkish Marmara and Black Seas

by Ulman, A., Zengin, M., Demirel, N., and Pauly, D. (2020). Front. Mar. Sci. 7:650. doi: 10.3389/fmars.2020.00650

In the original article, there was a mistake in Figure $\mathbf{1}$ as published. The legend of Figure 1B was duplicated from Figure 1A and incorrectly indicated an Exclusive Economic Zone (EEZ) in Marmara Sea. The EEZ line has been removed from both figure parts, along with the EEZ area of $11,700 \mathrm{~km}^{2}$. The spelling of the Bosphorus (Istanbul) Strait has been corrected as it was misspelled "Bosporus." In the original Figures 1A,B there were small maps with red squares showing the location of our study area. The squares have been removed from both figure parts and the map has been removed from Figure 1A. The corrected Figure 1 appears below.

The legend of Figure 1 has been updated accordingly. The correct legend appears below.

The authors apologize for this error and state that this does not change the scientific conclusions of the article in any way. The original article has been updated.

Frontiers Media SA remains neutral with regard to jurisdictional claims in published maps and institutional affiliations.

Copyright (๑) 2020 Ulman, Zengin, Demirel and Pauly. This is an open-access article distributed under the terms of the Creative Commons Attribution License (CC BY). The use, distribution or reproduction in other forums is permitted, provided the original author(s) and the copyright owner(s) are credited and that the original publication in this journal is cited, in accordance with accepted academic practice. No use, distribution or reproduction is permitted which does not comply with these terms. 
Unman et al.

Corrigendum: Lost Fish of Turkey

A

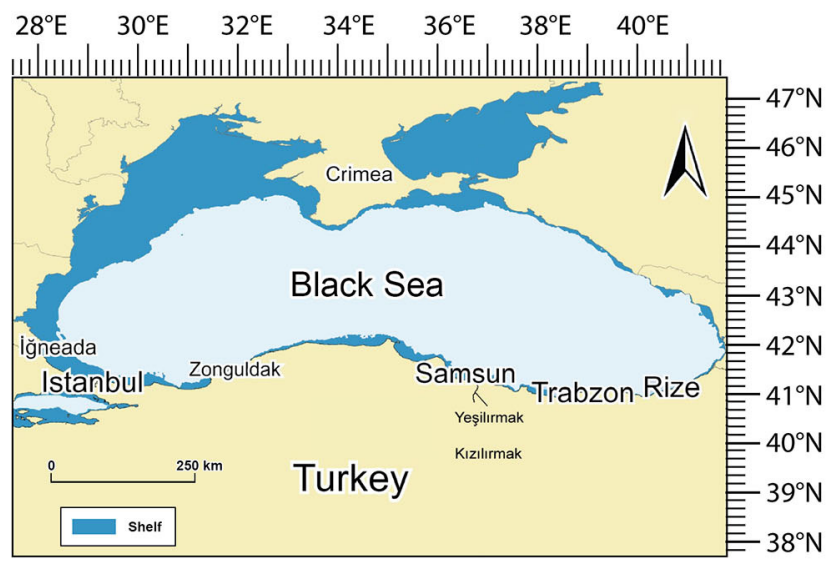

B

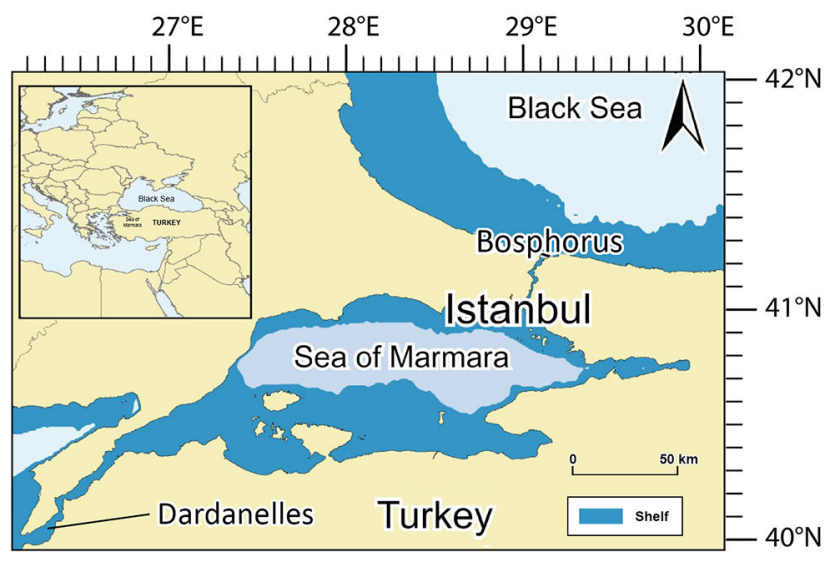

FIGURE 1 | (A) Black Sea and (B) the Sea of Marmara with the Bosporus and Istanbul in the Northeast and the Dardanelles Strait in the Southwest, also displaying some cities and rivers mentioned in the text, with latitude and longitude.

Frontiers in Marine Science | www.frontiersin.org

2

October 2020 | Volume 7 | Article 600242 